\title{
A 10 year data analysis of lymphatic system metastasis and recurrence in individuals affected by malignant tumors within the oral cavity and maxillofacial region
}

\author{
Adam Dreksler', Marcin Lenkowski', Michał Marcinkowski², Marian Tomasz Nowaczyk², \\ Krzysztof Osmola², Tomasz Pełczyński ${ }^{1}$, Gleb Radzewicz', Samir Rahma' \\ ${ }^{1}$ Student Scientific Circle in Department of Maxillofacial Surgery, Poznan University of Medical Sciences, Poland \\ ${ }^{2}$ Department of Maxillofacial Surgery, Poznan University of Medical Sciences, Poland
}

\begin{abstract}
Introduction. Tumors are only second to cardiovascular diseases as a cause of death. According to World Health Organization (WHO), these statistics will increase especially within aging and well-developed countries.

Aim. The aim of the research was to analyze the frequency of recurrences and lymph node involvement in individuals affected by malignant tumor of head and neck region. Special attention was paid to tumor location, sex, age of the affected individuals as well as histological appearance of the tumor.

Material and methods. The research team has analyzed medical data record base from 2002-2011 and selected a group of 1697 individuals treated for malignant tumors within the oral cavity and maxillofacial region.

Results. Reoperation was carried out on 192 patients due to recurrences and lymph node involvement; (11.3\%) of the study group. Patients were further subdivided into groups according to sex, age, histological appearance and anatomical location of tumor recurrence. Results were compared with the available literature.

Conclusions. Our data confirms the findings of other research groups in terms of accuracy of early diagnostic screening and its effect on final tumor treatment. It is also essential to accentuate the importance of post-treatment monitoring within first five years after initiation of treatment, which allows for an early determination of local recurrences and/or lymph node involvement.
\end{abstract}

Keywords: tumors of head, tumors of neck, recurrence.

\section{Introduction}

Tumors are only second to cardiovascular diseases as a cause of death. According to World Health Organization (WHO), these statistics will increase especially within aging and well-developed countries. In 2010, United States reported 36000 new cases of cancers involving the regions of oral cavity and head and neck. $90 \%$ of these carcinomas were diagnosed histologically as squamous cell carcinomas (SCC) [1]. Data acquired in Poland also shows an increasing trend of oral cancer occurrence. In 1963 there were 35328 new cases, in 1990,83470 , whereas in 2003, 121444, which is equivalent to an increase of risk by 3.43 times. In the region of Great Poland (Wielkopolska), situated in the western part of Poland, in 1999 there were 10316 new malignant cases, whereas in 2009, there were 12966 new cases (6554 men, 6412 women) which is equivalent to increase of $25 \%$ (2650). In 2009, the number of fatalities reported was 8258 . There has also been an increase in the number of tumors in the oral and head and neck region. In 1999, the Great Poland registered 815 new cases involving head and neck area, whereas in 2009, the number of 909 new cases [2]. The most 
common head and neck cancer is SCC. Despite the fact that there has been an improvement in SCC treatment, the number of post-treatment complications is still significant. Patients negligence in the early stages of cancer is the main reason for unfavorable prognosis and often leads to a high degree of tumor involvement. Data indicates that there has been a substantial increase in the number of head and neck carcinomas and unfortunately this unfavorable trend is expected to create a major social and medical burden.

\section{Aim}

The aim of the research was to analyze the frequency of recurrences and lymph node involvement in individuals affected by malignant tumor of head and neck region. Special attention was paid to tumor location, sex, age of the affected individuals as well as histological appearance of the tumor.

\section{Material and methods}

A particular group of individuals has been selected based on medical data record base from 2002-2011 and selected a group of patients operated due to tumors within the oral cavity, skeletal region of the maxilla and mandible as well as skin covering of the head and neck. Further analysis has been performed on a group of individuals on which reoperation was performed due to recurrence within the primary site or due to regional lymph metastasis. Patients were sub- divided into groups according to sex, age, histological appearance and anatomical location of tumor recurrence.

\section{Results}

According to medical data from ten years period from 2002-2011, 1697 individuals (612 females, 1085 males) were operated due to malignancy. The female/male ratio was (F/M) 1/1.77. The age of patients ranged from 9 to 96 years. The most common location of primary lesion of the tumor has been located in the floor of the mouth or alveolar part of mandible. Detailed location of primary lesions has been shown in Figure 1 . Histological analysis of oral mucosa showed SCC as the most commonly occurring carcinoma (Table 1).

The reason for the reoperation during analyzed period of time was the process of local recurrence and metastasis to the regional lymph nodes in 192 patients (69 females, 123 men), (F/M = 1.78) (Figures 2, 3). The age of re-operated patients varied from 21 to 90 years. The most numerous group consisted of patients aged from $51-60$ years (Table 2 ).

The greatest number of recurrences was found in patients in which primary lesion was located in maxillary and palatal region (39.1\%). The least commonly reoperated individuals presented with a primary lesion within soft tissues (gingival tissue, buccal vestibule and skin from unspecified parts of the face) and lymph nodes of the oral cavity region. $75.5 \%$ of recurrences occurred within the first 2 years. The average time of

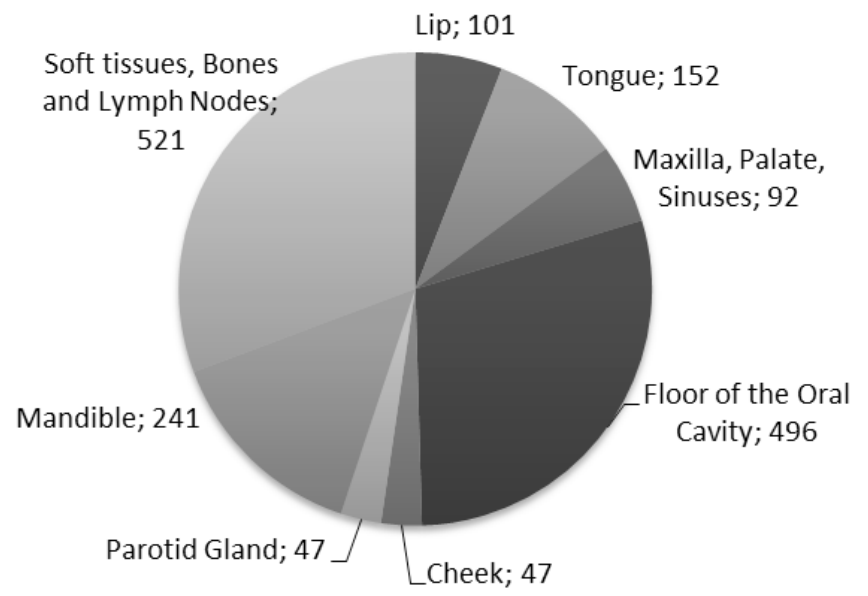

Figure 1. Primary location of tumors operated in 2002-2011

Table 1. Histological diagnosis of reoperated tumors

\begin{tabular}{cccccc}
\hline $\begin{array}{c}\text { Carcinoma } \\
\text { planoepitheliale }\end{array}$ & $\begin{array}{c}\text { Carcinoma } \\
\text { basocellulare }\end{array}$ & $\begin{array}{c}\text { Carcinoma } \\
\text { adenoidescysticum }\end{array}$ & Sarcoma & $\begin{array}{c}\text { Carcinoma } \\
\text { mucoepidermale }\end{array}$ & $\begin{array}{c}\text { Carcinoma } \\
\text { Solidum }\end{array}$ \\
\hline $168(87.5 \%)$ & $9(4.7 \%)$ & $6(3.1 \%)$ & $6(3.1 \%)$ & $2(1.0 \%)$ & $1(0.5 \%)$ \\
\hline
\end{tabular}




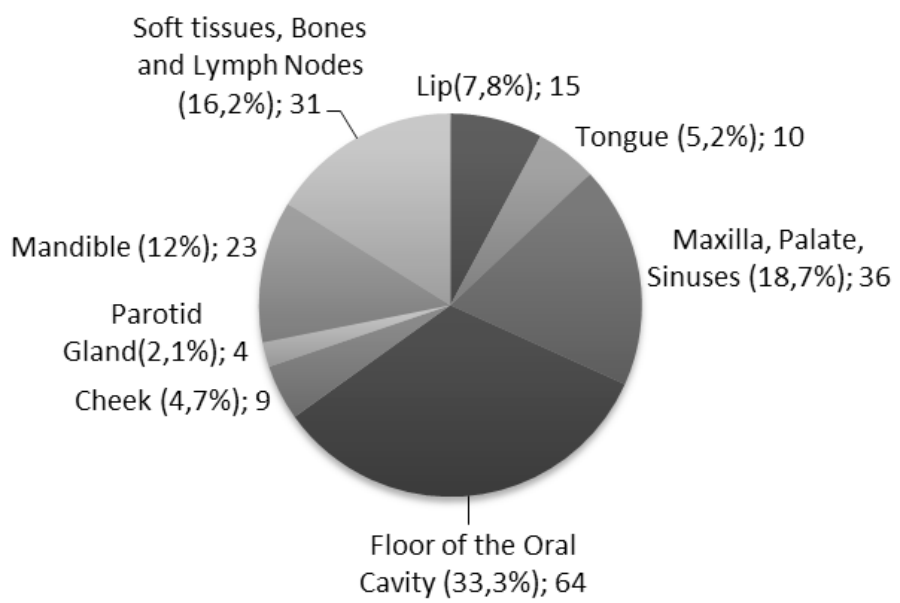

Figure 2. Number of surgical reoperations in specific primary locations of tumors

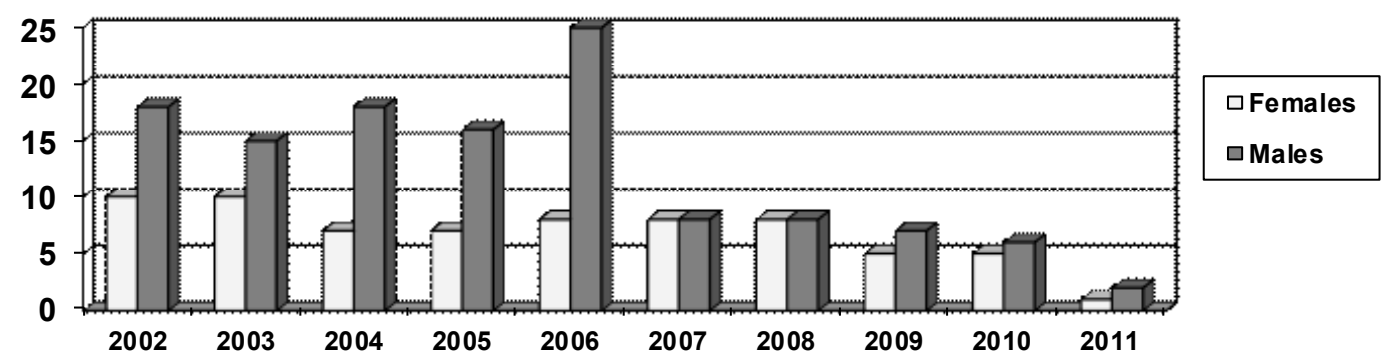

Figure 3. 192 patients treated due to malignant recurrences in 2002-2011 (69 females, 123 males)

Table 2. Age of reoperated patients

\begin{tabular}{ccccccc}
\hline & under 40 & $41-50$ & $51-60$ & $61-70$ & $71-80$ & over 80 years \\
\hline Females & 4 & 16 & 22 & 14 & 9 & 4 \\
\hline Males & 13 & 21 & 53 & 19 & 12 & 5 \\
\hline
\end{tabular}

recurrence, beginning with initial lesion to its removal, was about 15 months. Detailed description was presented in Figure 4.

\section{Discussion}

10 years of clinical observations provided us with a study group of 1697 patients treated for carcinoma. Annually, it averaged to 170 cases of oral and facial region. Comparison of data published in 1964-1994, by Flieger et al. [3], revealed 850 patients affected by malignancy (annually, 28 patients). Flieger's data revealed an increasing trend in the number of patients treated for carcinoma, confirming our hypothesis in terms of an increased number of carcinomas involving head and neck region. The peak of oncological involvement occured within the 5 and 6 decade with an apparent predominance of males [4]. Our results showed a similar pattern of age involvement.

According to the vast majority of literature, local and regional recurrences are observed within the first two years after initiation of treatment [1, 5-7]. Evaluation of our data has also showed this particular trend. Wolfensberg [8] reported loco regional recurrences in 18 out of 96 affected individuals within the three years after treatment initiation (18.7\%). According to Petrisor and Fernandes [1] recurrences occur 2 years following treatment initiation, whereas Agra et al. [5] report $62.2 \%$ of recurrences, following the first year following treatment commencement. Recurrences within the lymph nodes were also reported within the same time frame by Kokenmuller et al. [6]. The data above indicates that the first two to three years following the surgical procedure, are a key determinant in diagnostic process of recurrences.

Recurrences were observed more frequently in individuals with a higher grade of malignancy G2-G3. This phenomenon was also observed by other authors [9, 10]. Location of the tumor and its recurrence in tumors of the mandible, tongue and buccal mucosa were statistically different among female group. According to Szybiak et al. [11], however, the frequency of tumor recur- 


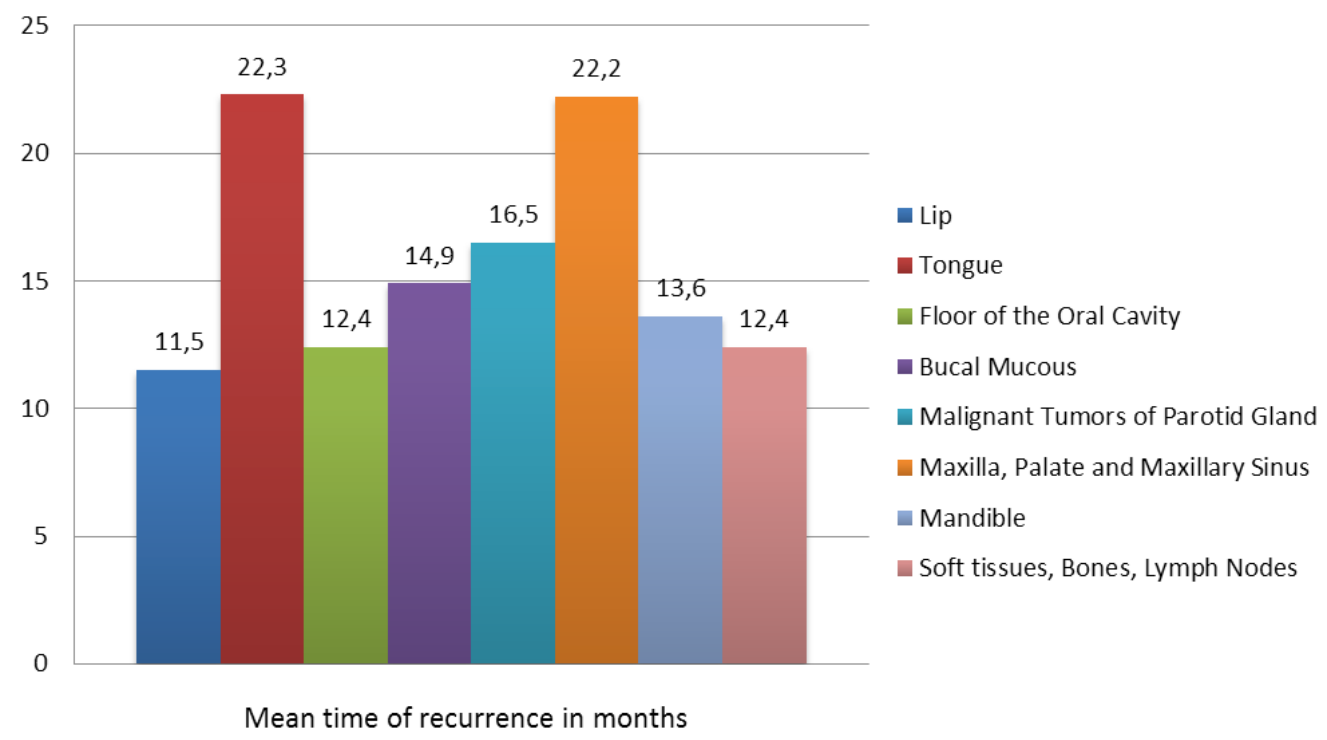

Figure 4. The average time of recurrence in specific primary locations of tumors

rence in the tongue region and floor of the mouth is 4 times higher in men than females. Our data correlates with the statistics of Szybiak et al. [11], who reported an increase of 16 percent recurrence rate. There is an apparent increase in frequency of tumor recurrence in the mandibular region and buccal mucosa in individuals with grade score $\mathrm{G} 1$.

There has also been reported a gender disproportionality, with a recurrence ratio of 55 to 9 in favor of the females, as well as a higher grade of pathological malignancy of the floor of the mouth tumor. According to our data, there has been a more frequent recurrence process within the region of the maxilla: $39.1 \%$. (Table 3), without any gender difference, but with a higher grade of malignancy. The major reason for such high recurrence rate is a high grade of histological malignancy (G) as well as an anatomical complexity of the maxillary region, making a surgical intervention extremely challenging. Our data correlates with the literature and indicates a predominance of squamous cell carcinoma (87.5\%) (Table 1). According to American research data [1], 90\% of cancers affecting head, neck, and oral cavity region is squamous cell carcinoma.

Boysen et al. [12], on the other hand, stress that routine control after a three year time period following treatment initiation is rarely indicated. Boysen et al. [12], also does not recommend it in those in whom effective treatment methods have been exhausted. Visscher and Mani [13] claim that routine check-ups are crucial and emphasize that determination of location and grade of involvement are instrumental in determination of follow-up treatment duration. Hass et al. [14], emphasize the importance of routine check-ups in order to establish loco-regional recurrences, whenever there are feasible chances for effective treatment and of improvement of health. Early surgical intervention increases chances for successful treatment. According to the literature the clinical disease advancement has an instrumental influence on prognosis and survival of affected individuals. This has also been confirmed by Agra et al. [5].

In those in which recurrence has significantly advanced, as well as in those whom advanced primary

Table 3. Rate of recurrence after primary tumor operation in specific primary locations

\begin{tabular}{lc}
\hline \multicolumn{1}{c}{ Primary location } & Rate of recurrence \\
\hline Maxilla, Palate, Sinuses & $39.1 \%$ \\
\hline Cheek & $19.1 \%$ \\
\hline Lip & $14.9 \%$ \\
\hline Floor of the Oral Cavity & $13.0 \%$ \\
\hline Mandible & $9.5 \%$ \\
\hline Parotid Gland & $8.5 \%$ \\
\hline Tongue & $6.6 \%$ \\
\hline Soft tissues, Bones and Lymph Nodes & $6.0 \%$ \\
\hline
\end{tabular}


lesion was previously treated surgically, the treatment outcomes are poor $[15,16]$. Early diagnosis and immediate treatment commencement has greatly enhanced the tumor control rate within the head and neck region $[8,9,17,18]$.

\section{Conclusions}

Our data confirms the findings of other research groups in terms of accuracy of early diagnostic screening and its effect on final tumor treatment. It is also essential to accentuate the importance of post-treatment monitoring within first five years after initiation of treatment, which allows for an early determination of local recurrences and/or lymph node involvement.

\section{Acknowledgements}

\section{Conflict of interest statement}

The authors declare that there is no conflict of interest in the authorship or publication of contribution.

\section{Funding sources}

There are no sources of funding to declare.

\section{References}

1. Petrisor D, Fernandes R. Reoperative maxillofacial oncology, Oral Maxillofac Surg Clin North Am. 2011 Feb;23(1):161-168.

2. Nowotwory złośliwe w Wielkopolsce w 2009 roku. Biuletyn nr 8 Wydawnictwo Wielkopolskiego Centrum Onkologii w Poznaniu 2011; 9-19.

3. Flieger S, Lewandowski L, Osmola K, Nowaczyk MT. Leczenie chorych onkologicznych w klinice chirurgii Szczękowo-Twarzowej w Poznaniu w okresie 30 lat. Poznańska Stomatologia. 1994:13-17.

4. Lara PC, Bordón E, Rey A, Moreno M, Lloret M, Henríquez-Hernánde LA. IGF-1R expression predicts clinical outcome in patients with locally advanced oral squamous cell carcinoma. Oral Oncol. 2011 Jul;47(7):615-619.

5. Agra IM, Carvalho AL, Pinto CA, Martins EP, Filho JG, Soares FA et all. Biological markers and prognosis in recurrent oral cancer after salvage surgery. Arch Otolaryngol Head Neck Surg. 2008 Jul;134(7):743-749.

6. Kokemuller H, Brachvogel P, Eckardt A, Hausamen JE. Effectiveness of neck dissection in metastasizing mouth carcinoma. Uni- and multivariate analysis of factors of influence. Mund Kiefer Gesichtschir. 2002 Mar;6(2): 91-97.

7. Rowe DE, Carroll RJ, Day CL Jr. Prognostic factors for local recurrence, metastasis, and survival rates in squamous cell carcinoma of the skin, ear, and lip. Implications for treatment modality selection. J Am Acad Dermatol. 1992 Jun;26(6):976-990.

8. Wolfensberger M, Albrecht S, Muller W, Zbaren P, Dulguerov $\mathrm{P}$, Arnoux $\mathrm{A}$ et all. Follow-up after histologically verified radical resection of early cancers of the mouth cavity: results of a prospective multicenter study. Schweiz Med Wochenschr Suppl. 2000;116:12S-14S.

9. Agra IM, Filho JG, Martins EP, Kowalski LP. Second salvage surgery for re-recurrent oral cavity and oropharynx carcinoma. Head Neck. 2010 Aug;32(8):997-1002.

10. Wong LY, Wei WI, Lam LK, Yuen AP. Salvage of recurrent head and neck squamous cell carcinoma after primary curative surgery. Head Neck. 2003 Nov;25(11):953-959.

11. Szybiak B, Trzeciak P, Golusiński W. Role of extended histological examination in the assessment of local recurrence of tongue and floor of the mouth cancer. Rep Pract Oncol Radiother. 2012 Nov;17(6):319-323.

12. Boysen M, Lövdal O, Tausjö J, Winther F. The value of follow-up in patients treated for squamous cell carcinoma of the head and neck. Eur J Cancer. 1992;28(2-3): 426-430.

13. de Visscher AV, Manni JJ. Routine long-term follow-up in patients treated with curative intent for squamous cell carcinoma of the larynx, pharynx, and oral cavity. Does it make sense? Arch Otolaryngol Head Neck Surg. 1994 Sep;120(9):934-939.

14. Haas I, Hauser U, Ganzer U. The dilemma of follow-up in head and neck cancer patients. Eur Arch Otorhinolaryngol. 2001 May;258(4):177-183.

15. Zafereo ME, Hanasono MM, Rosenthal DI, Sturgis EM, Lewin JS, Roberts DB et al. The role of salvage surgery in patients with recurrent squamous cell carcinoma of the oropharynx. Cancer. 2009 Dec;115(24):5723-5733.

16. Arnold DJ, Goodwin WJ, Weed DT, Civantos FJ. Treatment of recurrent and advanced stage squamous cell carcinoma of the head and neck. Semin Radiat Oncol. 2004 Apr;14(2):190-195.

17. Tsang RK, Chung JC, To VS, Chan JY, Ho WK, Wei WI. Efficacy of salvage neck dissection for isolated nodal recurrences in early carcinoma of oral tongue with watchful waiting management of initial NO neck. Head Neck. 2011 Oct;33(10):1482-1485.

18. Schiefke F, Hildebrandt G, Pohlmann S, Heinicke F, Hemprich $A$, Frerich $B$. Combination of surgical resection and HDR brachytherapy in patients with recurrent or advanced head nad neck carcinomas. J Craniomaxillofac Surg. 2008 Jul;36(5):285-292.

Acceptance for editing: 2015-10-05 Acceptance for publication: 2015-12-17

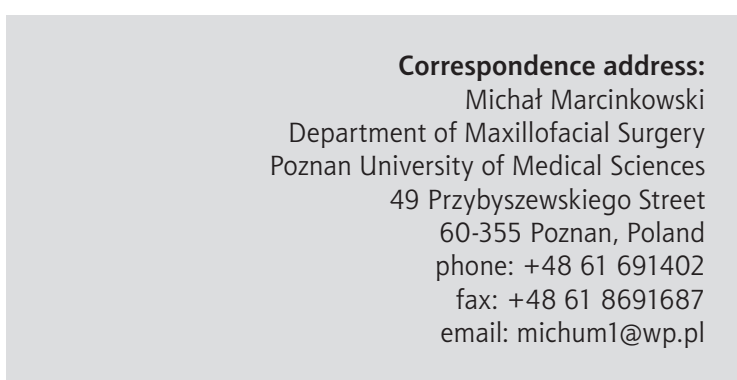

